\title{
Natural attenuation can lead to environmental resilience in mine environment
}

\author{
Elisabetta Dore ${ }^{\mathrm{a}}$, Dario Fancello ${ }^{\mathrm{a}}$, Nicola Rigonat ${ }^{\mathrm{a}}$, Daniela Medas ${ }^{\mathrm{a}}$, Rosa Cidu ${ }^{\mathrm{a}}$, Stefania Da Pelo ${ }^{\mathrm{a}}$, \\ Franco Frau $^{\mathrm{a}}$, Pierfranco Lattanzi ${ }^{\mathrm{b}}$, Pier Andrea Marras ${ }^{\mathrm{a}}$, Carlo Meneghini ${ }^{\mathrm{c}}$, Francesca Podda ${ }^{\mathrm{a}}$, \\ Valentina Rimondi $^{d}$, Robert L. Runkel ${ }^{\mathrm{e}}$, Briant Kimball ${ }^{\mathrm{f}}$, Richard B. Wanty ${ }^{\mathrm{g}}$, Giovanni De Giudici ${ }^{\mathrm{a}, *}$ \\ a Department of Chemical and Geological Sciences, University of Cagliari, Cittadella Universitaria, Monserrato, 09042, CA, Italy \\ ${ }^{\mathrm{b}}$ CNR-IGG, UOS Firenze, Via G. La Pira 4, I-50121, Firenze, Italy \\ c Department of Sciences, University of Roma Tre, 00146, Rome, Italy \\ ${ }^{\mathrm{d}}$ Dipartimento di Scienze della Terra, Università di Firenze, Via La Pira 4, Firenze, I-50121, Italy \\ e U.S. Geological Survey, Colorado Water Science Center, 3215 Marine St, Bldg 6 Boulder, CO, 80303, USA \\ ${ }^{f}$ U.S. Geological Survey, 2329 W Orton Circle, Salt Lake City, UT, 84117, USA \\ ${ }^{g}$ U.S. Geological Survey, MS 963 Denver Federal Center, Denver, CO, 80225, USA
}

\section{A R T I C LE IN F O}

Handling editor. Michael Kersten

\section{Keywords}

Environmental resilience

Mine pollution

Biominerals

Biogeochemical barriers

Metal load

\begin{abstract}
A B S T R A C T
Four streams flowing in the Iglesiente and Arburese mine districts (SW Sardinia, Italy), exploited for zinc ( $\mathrm{Zn}$ ) and lead $(\mathrm{Pb})$ extraction from sulphides and secondary non-sulphide mineralization (calamine ores), have been studied combining investigations from the macroscale (hydrologic tracer techniques) to the microscale (X-ray powder diffraction, scanning electron microscopy, X-ray absorption spectroscopy). In the investigated area, concerns arise from release of metals to water during weathering of ore minerals and mine-waste. Specifically, $\mathrm{Zn}$ is observed at extremely high concentrations (10s of $\mathrm{mg} / \mathrm{L}$ or more) in waters in some of the investigated catchments. The results from synoptic sampling campaigns showed marked differences of Zn loads, from $6.3 \mathrm{~kg} / \mathrm{day}$ (Rio San Giorgio) to $2000 \mathrm{~kg}$ /day (Rio Irvi). Moreover, natural attenuation of metals was found to occur i) through precipitation of Fe compounds (Fe oxy/hydroxides and "green rust"), ii) by means of the authigenic formation of metal sulphides promoted by microbial sulphate reduction, iii) by metal intake in roots and stems of plants (Phragmites australis and Juncus acutus) and by immobilization in the rhizosphere, and iv) by cyanobacterial biomineralization processes that lead to formation of Zn-rich phases (hydrozincite and amorphous Zn-silicate). The biologically mediated natural processes that lead to significant abatement and/or reduction of metal loads, are the response of environmental systems to perturbations caused from mine activities, and can be considered part of the resilience of the system itself. The aim of this study is to understand the effect of these processes on the evolution of the studied systems towards more stable and, likely, resilient conditions, e.g. by limiting metal mobility and favoring the improvement of the overall quality of water. The understanding of how ecosystems adapt and respond to contamination, and which chemical and physical factors control these natural biogeochemical barriers, can help to plan effective remediation actions.
\end{abstract}

\section{Introduction}

Mining activities affect large areas all over the world, modifying the landscape and the environment. In Europe, China and USA the area affected by mining operations averages $0.1 \%$ and hundreds of thousands of abandoned mine sites remain after centuries of mining activity (Arbogast et al., 2000; Lin and Ho, 2003; EUROSTAT, 2012). Mine activity leads to an increase in metal concentration due to dispersal processes through different paths, dissolution and suspension of fine minerals in waters, erosion and transport by wind, availability of metals to biosphere and their access to the food chain. For this rea- son, mining activity is perceived to be a concern of local, regional and global interest (Rice and Herman, 2012).

Mining activity consists of excavation of large volumes of rocks and production of mine wastes rich in metals and pollutants that can be dispersed and are often prone to erosion. The impact of mine activity is often the creation of vegetation-free landscapes (Yang et al., 2018 and references therein), where erosion processes dominate. However, natural systems often respond to environmental stress by adopting survival strategies (Batty et al., 2006; Sheoran and Sheoran, 2006). The interaction between the geosphere and the biosphere at the interface of surface water and groundwater takes place at the hy-

\footnotetext{
* Corresponding author.

E-mail address: gbgiudic@unica.it (G. De Giudici)
} 
porheic zone (Runkel et al., 2003; Bencala, 2011) and can lead to the development of natural chemical processes responsible for the attenuation of metal content. Pioneer plants are able to grow in deeply polluted sediments due to their ability to adapt and often behave as metal excluders (Medas et al., 2015, 2019; De Giudici et al., 2015, 2017; Caldelas and Weiss, 2017; Boi et al., 2020). Plants also have the ability to remove trace metals from water through biological uptake and surface adsorption, and can form biominerals to decrease the bioavailability of metals (Sheoran and Sheoran, 2006; Caldelas and Weiss, 2017). For these reasons, engineered wetlands are often built to remediate dispersion of pollutants from mines and other polluted environments (An et al., 2011; Walaszek et al., 2018). Moreover, some bacteria, fungi and microfungi are able to adapt to extreme metal-rich environments indicating an environmental response toward metastable equilibria (Igiri et al., 2018; Cecchi et al., 2019a). For instance, fungi can dissolve pyrite at enhanced rates (Cecchi et al., 2019b, 2019c), driving mine waste systems toward more favourable conditions for biological growth.

The resilience of a system is often referred to as population dynamics (Holling, 1973). Ecological systems comprise many compartments, including minerals, biominerals, plants, waters, microbes, flora and fauna, etc.. Thus, resilience can be defined in different ways as highlighted by Gollner et al. (2017). Resilience in mining environments can be defined as the amount of anomalies that an ecosystem can absorb before undergoing irreversible mutations, or the time taken by an ecosystem to recover the conditions prior to a disturbance (Gollner et al., 2017). As far as we know, studies connecting the role of (bio)minerals with the response of natural systems to perturbation due to mine activities are still lacking.

Engineered and natural wetlands are ecosystems resilient to mine pollution as they allow bioprecipitation and immobilization of metals in sediments below the redox interface, where reducing conditions and availability of electron donors allow sulphur-reducing bacteria to produce sulphide ions that combine with metals to form biomineralization rich in base metal sulphides (Smieja-Król et al., 2015; De Giudici et al., 2017). Environmental resilience can be then tightly related to mineral dissolution or precipitation, particularly when mineral reactions decrease bioavailability of metals.

Mining activity linked to $\mathrm{Pb}$ and $\mathrm{Zn}$ production represented the main economic activity for centuries in the Iglesiente and Arburese mine districts (SW Sardinia, Italy), and in the process, impacted surrounding soil and waters. From 2011 to 2013 several synoptic sampling campaigns were carried out by the University of Cagliari and the United States Geological Survey (USGS) using the tracer technique to study the effects of mining activities on some selected streams draining abandoned mine areas in SW Sardinia (De Giudici et al., 2014, 2017, 2018, 2019). This technique allows one to quantify the effects of mine drainage at the watershed scale, and to identify spatial patterns of contamination (Buxton et al., 1997). For this purpose the tracer-injection approach was combined with spatially detailed synoptic sampling to calculate river discharge and the change of contaminant loads, as well as to assess the influence of sampled inflows and unsampled underground sources on river water chemistry (Kimball et al., 2002). The present work focuses on the processes that, from the macro scale to the micro scale, influence the fate of different metals (mainly $\mathrm{Zn}$ ) in the studied streams, with particular attention on processes occurring in the hyporheic zone, where the geo-bio-hydrosphere interaction is favoured.

This study is aimed at understanding the resilience of the environmental systems assuming gradual revegetation in the streambed of historically mine polluted environments. We selected four different contaminated areas with different density of vegetation cover in the streambed. Then we studied the apparent differences through the characterization of the natural processes occurring in the hyporheic zone, that lead not only to the decrease of metal load and to the improvement of water quality, but allow the system to evolve toward more sta- ble conditions. The understanding of these processes can be of great help in planning remedial actions.

\section{Study area and mining history}

The investigated area comprises the Iglesiente and Arburese districts (SW Sardinia, Italy), where mining linked to the production of $\mathrm{Pb}$ and $\mathrm{Zn}$ has been the main economic activity for centuries (Fig. 1). The geologic setting of the area mainly consists of a Paleozoic sedimentary succession, hosting the ore bodies, and igneous rocks (Pillola et al., 1998; Boni et al., 2003). The post-Paleozoic successions are represented by the sedimentary Mesozoic and Cenozoic units (Carmignani et al., 1996), and the volcanic complex of Monte Arcuentu (upper Oligocene-lower Miocene) (Assorgia et al., 1984). Eolian dunes (Piscinas dunal complex) and fluvial deposits represent the coastal and internal Quaternary covers (Fig. 1).

In the Montevecchio-Ingurtosu district the mineralization mainly consists of a set of veins of galena ( $\mathrm{PbS}$ ) and sphalerite ( $\mathrm{ZnS}$ ) associated with quartz $\left(\mathrm{SiO}_{2}\right)$, siderite $\left(\mathrm{FeCO}_{3}\right)$ and other sulphide minerals (Cuccuru et al., 2016; Moroni et al., 2019). In the Iglesiente mining district the Paleozoic succession hosts the so-called "Metalliferous Ring"; the mineralizations consist of massive sulphide ore bodies and stratabound deposits, and the minerals are sphalerite, galena and pyrite $\left(\mathrm{FeS}_{2}\right)$, with associated barite $\left(\mathrm{BaSO}_{4}\right)$ and calamines (mainly composed of smithsonite $\left(\mathrm{ZnCO}_{3}\right)$, hemimorphite $\left(\mathrm{Zn}_{4} \mathrm{Si}_{2} \mathrm{O}_{7}(\mathrm{OH})_{2} \cdot \mathrm{H}_{2} \mathrm{O}\right)$ and hydrozincite $\left(\mathrm{Zn}_{5}\left(\mathrm{CO}_{3}\right)_{2}(\mathrm{OH})_{6}\right)$ (Boni, 1994; Bechstädt and Boni, 1994).

In the 19th and 20th centuries, when the mine exploitation reached its peak, the study area was the main mining district of Sardinia, the most important mining region of Italy. The mines mainly produced $\mathrm{Zn}$ and $\mathrm{Pb}$ from galena $(\mathrm{PbS})$ and sphalerite $(\mathrm{ZnS})$, often accompanied in the ore bodies by pyrite $\left(\mathrm{FeS}_{2}\right)$ and chalcopyrite $\left(\mathrm{CuFeS}_{2}\right)$, calamine (smithsonite and hemimorphite) and barite $\left(\mathrm{BaSO}_{4}\right)$; locally secondary products were $\mathrm{Ag}$ and other metals (Bi, Cd, Co, Cu, Sb, and Ge; De Giudici et al., 2019). When all the mine activities ceased in each of these districts (1968-1995), the mining wastes as well as the residues of metallurgical extraction were abandoned in dumps without remedial action. Moreover, after the mine closures most of the adits were flooded as a consequence of stopping the dewatering plants. Therefore, the interaction of rain water, surface water and water flowing in flooded adits with the minerals of waste and adits, and with the highly reactive residues of metallurgical extraction, allows the mobilisation of contaminants causing various environmental impacts.

The climate of the area is characterized by a dry season from May to September, with occasional showers, and wetter autumn and winter seasons. The mean annual temperatures range between 15 and $17{ }^{\circ} \mathrm{C}$, the rainfall between about 600 and $800 \mathrm{~mm}$ (R.A.S, 1998; R.A.S., 2013; RAS, http://www.regione. Sardegna.it/j/v/ 25 ? $\mathrm{s}=131338 \& \mathrm{v}=2 \& \mathrm{c}=5650 \& \mathrm{t}=1$ ).

The objects of this study are the streams flowing in the mining areas impacted by the mine waste and residues of industrial extraction. They are: the Rio Montevecchio, Rio Irvi and Rio Naracauli, that flow in the Montevecchio-Ingurtosu district; and the Rio San Giorgio, which flows in the Iglesias district (Fig. 2).

\section{Experimental}

\subsection{Core sample collection and analysis}

Intact core samples of Rio San Giorgio (De Giudici et al., 2017), Rio Naracauli (new data) and Rio Montevecchio (Atzori, 2013) stream sediments were collected through a core sampler (Atlas Copco's COBRA) and samples were stored in sealed plastic bags (Fig. 2). After drying at room temperature, a representative portion of each recognizable layer of core samples was ground in an agate mortar to perform the mineralogical characterization through X-ray powder diffraction (XRPD). The XRPD patterns were collected in the 5-70 $2 \theta$ angular range, using an automated PANanalytical X'pert Pro diffractome- 


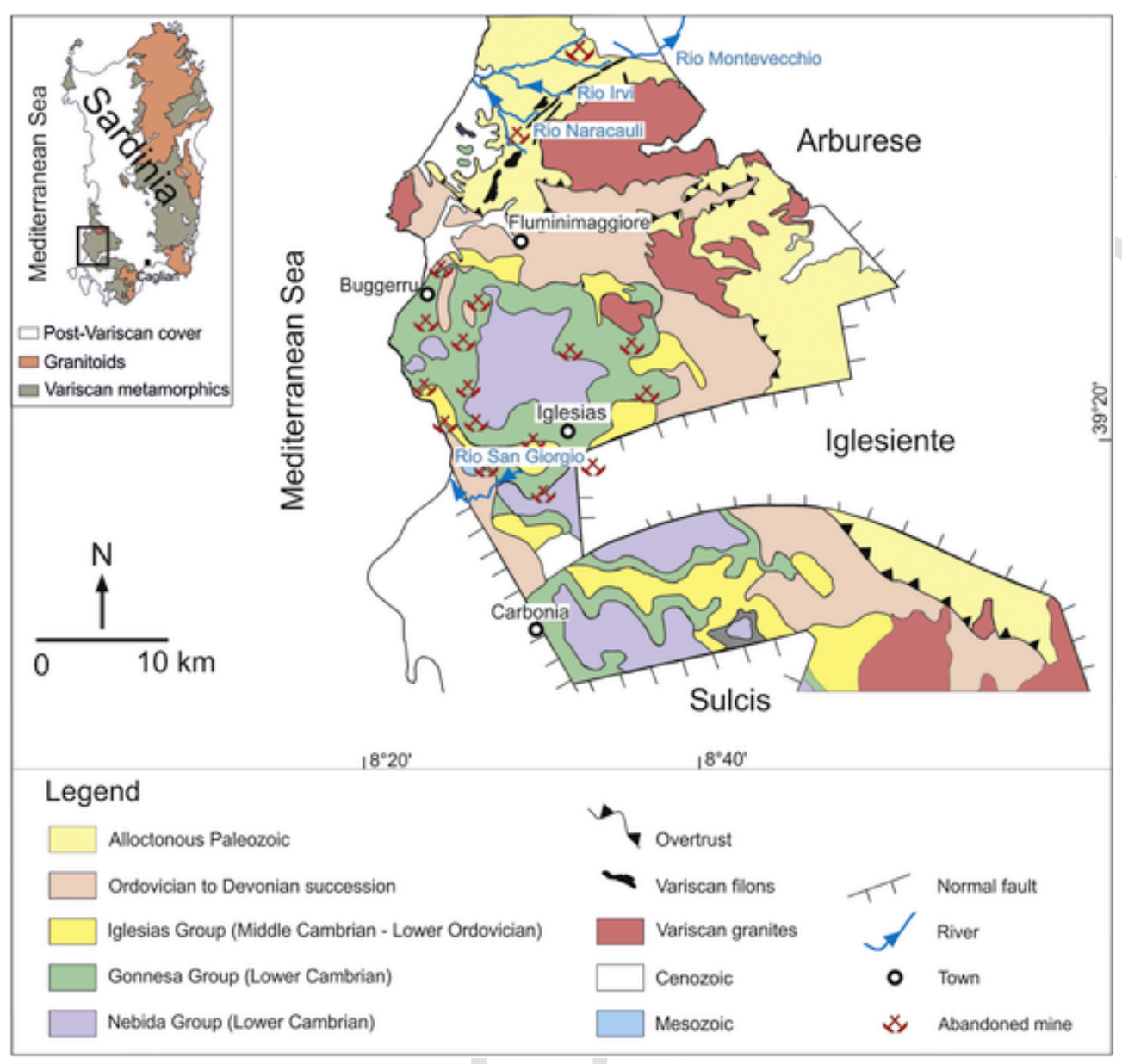

Fig. 1. Schematic geological setting of the study area (Boni et al., 2003, modified).

ter, with Ni-filtered $\mathrm{Cu} \mathrm{K} \alpha 1$ radiation $(\lambda=1.54060 \AA)$, operating at $40 \mathrm{kV}$ and $40 \mathrm{~mA}$, using the X'celerator detector. Scanning electron microscopy (SEM) analysis was performed by a FEI Quanta 200 equipped with a ThermoFisher UltraDry energy dispersive spectroscopy (EDS) detector at the CeSAR laboratory (University of Cagliari).

\subsection{Plants collection and analyses}

Samples of Phragmites australis were collected in the Rio San Giorgio (De Giudici et al., 2017) and Rio Naracauli (new data) streambed. After plant harvesting, rhizosphere samples (defined here as the soil portion within $2 \mathrm{~mm}$ of the roots) were recovered by shaking and gently wiping the roots and dried at room temperature. The plant roots were washed with deionized water until the rinse water was clear, and then they were washed four times with ultrapure water (Millipore, Milli-QC, $18.2 \mathrm{M} \Omega \mathrm{cm}^{-1}$ ). Finally, roots were dried at room conditions. The plant samples and rhizosphere materials were dried at about $30^{\circ} \mathrm{C}$ and ground immediately after their collection. Samples of root sections were prepared as described in De Giudici et al. (2015) and Medas et al. (2015) for soft X-ray microscopy combined with low energy $\mathrm{X}$-ray fluorescence (LEXRF) mapping analysis, performed at the TwinMic (Kaulich et al., 2006; Gianoncelli et al., 2016a, 2016b) beamline at ELETTRA, Trieste (Italy). The TwinMic microscope was operated in scanning transmission mode (STMX, Morrison et al., 2006; Gianoncelli et al., 2006, 2009, 2013). The X-ray beam energy (E 1/4 $1.985 \mathrm{keV}$ ) was chosen to ensure the best excitation and detection of Si, $\mathrm{Al}$, and $\mathrm{Zn}$, with a spatial resolution (X-ray spot size) of $1 \mu \mathrm{m} \times 1 \mu \mathrm{m}$, as a compromise between good XRF signal and dimension of the fea- tures of interest. The XRF elemental maps were deconvoluted and analysed with PyMCA software (Sole et al., 2007).

$\mathrm{X}$-ray absorption spectroscopy (XAS) measurements were carried out at the Zn K-edge $(9.659 \mathrm{keV})$ at the ELETTRA-XAFS beamline (Trieste, Italy) (Di Cicco et al., 2009). Samples were pressed in solid pellets, and the XAS measurements were carried out in transmission and fluorescence geometry keeping the samples at liquid nitrogen temperature. A set of reference compounds was also measured in transmission geometry for sake of comparison and used for X-ray absorption near edge structure (XANES) interpretation by linear combination analysis (LCA, Benfatto and Meneghini, 2014). For details on data refinement, see Meneghini et al. (2012) and De Giudici et al. (2017).

\section{Results and discussion}

\subsection{Metal loads at different Sardinia catchments}

In this section we compare the results from four different synoptic sampling campaigns in four mine-affected rivers in Sardinia (for details on water sample collection and analysis and for the tracer-injection technique see De Giudici et al., 2014, 2017, 2018, 2019). The synoptic sampling campaigns were conducted in different years, during late spring and after the rainy season, overall under a similar and steady hydrogeological regime. Waters of Rio Naracauli and Rio Irvi were collected respectively at the end of May and the beginning of June 2011. The sampling of Rio San Giorgio was conducted at the beginning of June 2012, and Rio Montevecchio was sampled between the end of May and the beginning of June 2013 (De Giudici et al., $2014,2017,2018,2019)$. The discharge of the rivers was very similar between values of 20 and $30 \mathrm{~L} / \mathrm{s}$ (Fig. 3a). Despite similar values of 


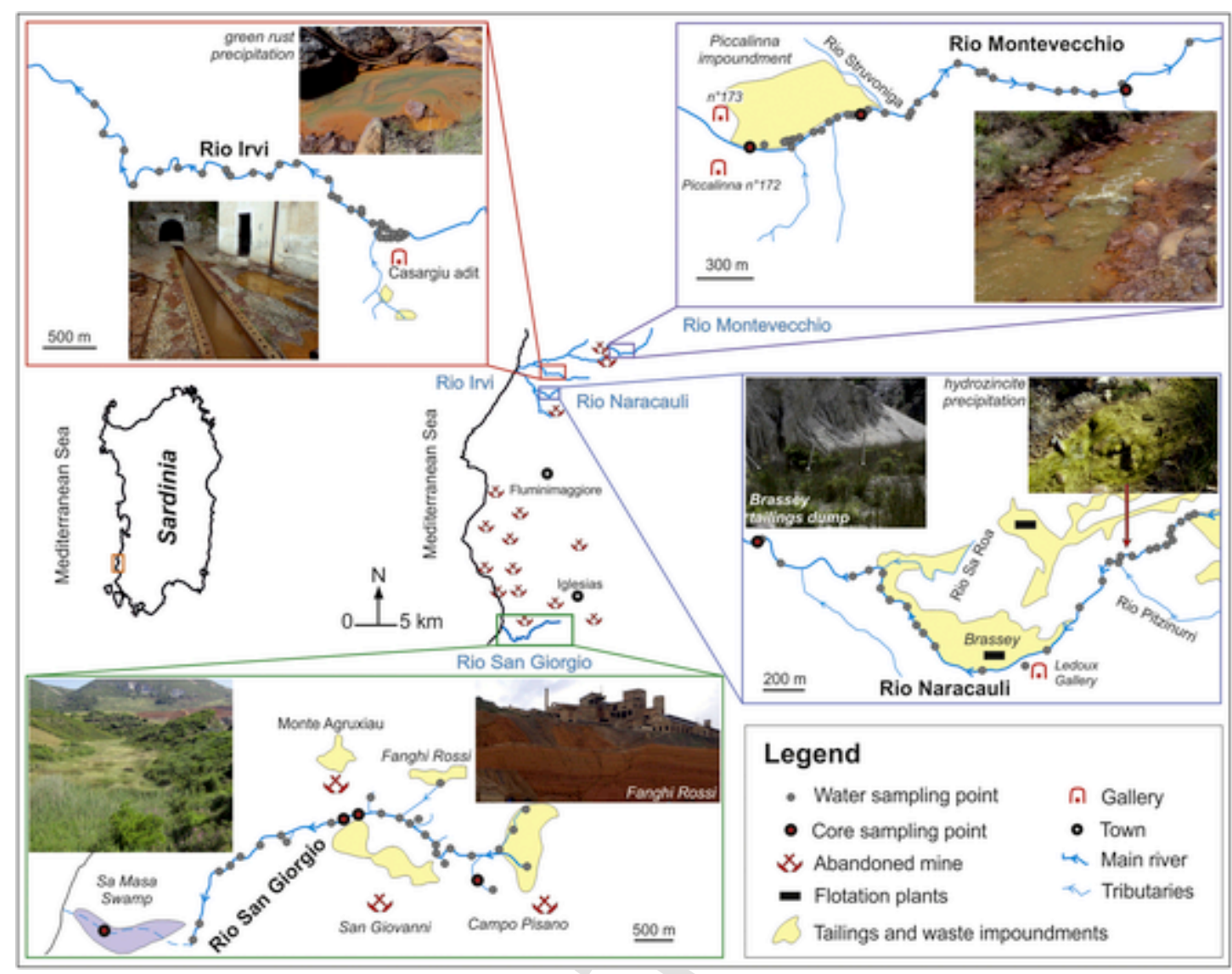

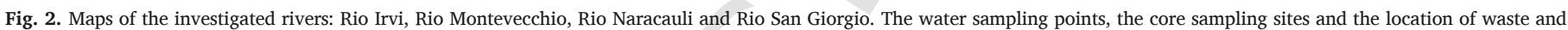
tailings impoundments are showed (The Fanghi Rossi photo comes from https://www.flickr.com/photos/7524642@N04/437433890/).

river discharge, metal loads, particularly $\mathrm{Zn}$, show differences of up to three orders of magnitude among the streams studied (Fig. 3b).

The Rio San Giorgio receives seepages from three main sources of pollution: the Campo Pisano, the San Giorgio and the "Fanghi Rossi" mine waste dams (Fig. 2). The Campo Pisano and San Giorgio dams consist of embankments of flotation mud commonly rich in carbonate minerals (calcite, dolomite, smithsonite, ankerite, etc.) and pyrite. The "Fanghi Rossi" dump is constituted by fine-grained particles $(<40 \mu \mathrm{m})$ of iron oxyhydroxides (especially goethite), residual smithsonite and abundant gypsum, resulting from Zn extraction, mainly from smithsonite, through electrolytic treatment (Cidu and Fanfani, 2002). Other contamination sources are the mine wastes along the streambed and other wastes dispersed in the catchment. Due to the inflow of tributaries draining mining waste and tailings, the chemical composition of water was found to change from $\mathrm{CaMg}-\mathrm{HCO}_{3}$ with circumneutral $\mathrm{pH}$, upstream, to a dominant $\mathrm{CaMg}-\mathrm{HCO}_{3}-\mathrm{SO}_{4}$ and $\mathrm{CaMg}-\mathrm{SO}_{4}$ composition and slightly alkaline $\mathrm{pH}$, downstream (pH 7.7 - 8.3) (De Giudici et al., 2017). Along the first $600 \mathrm{~m}$, the discharge of Rio San Giorgio was almost constant (17.4 L/s) and the Zn load was below $0.1 \mathrm{~kg} /$ day (Fig. 3a and b). In the river section between 600 and $2300 \mathrm{~m}$ downstream from the injection point, the discharge increased continuously, up to $28.8 \mathrm{~L} / \mathrm{s}$, and the $\mathrm{Zn}$ load, after a small increase, showed a peak of $6.3 \mathrm{~kg} /$ day attributable to the contributions of waters flowing from the "Fanghi Rossi" dump. Then, the $\mathrm{Zn}$ load decreased sharply to $3 \mathrm{~kg} /$ day while the discharge remained almost constant $(28.8 \mathrm{~L} / \mathrm{s})$. From $3000 \mathrm{~m}$ downstream until the end of the study reach, both the discharge and the $\mathrm{Zn}$ load increased moderately up to $36.7 \mathrm{~L} / \mathrm{s}$ and $4.8 \mathrm{~kg} /$ day, respectively.

The Rio Naracauli originates from the Ingurtosu mine and flows into the Mediterranean Sea after about $8 \mathrm{~km}$. Samples for the synoptic sampling were collected along the first $3 \mathrm{~km}$. The discharge slightly in- creased from the input of the Ingurtosu mine tunnel along the first $600 \mathrm{~m}(0.44-1.31 \mathrm{~L} / \mathrm{s})$, then progressive and sharp increments were observed till the end (up to $35.2 \mathrm{~L} / \mathrm{s}$ ). The major inputs came from both surface and groundwater inflows of Rio Pitzinurri and Ledoux Gallery, and drainages of mine-waste dumps along the river banks, the biggest of which is the Brassey Mill tailing dump (Figs. 2 and 3a). The Zn load, after slight fluctuations in the first hundreds of meters, decreased down to $0.21 \mathrm{~kg} /$ day. This is the lower value determined along the studied reach, before the confluence of Rio Pitzinurri. From the confluence of Rio Pitzinurri the Zn load progressively increased (27.3 kg/ day) until $2500 \mathrm{~m}$ and, in the lowest reach, increased slightly up to $28 \mathrm{~kg}$ /day. Water flowing from the Ingurtosu mine adit had high $\mathrm{Zn}$ concentration $(63.6 \mathrm{mg} / \mathrm{L})$ but, due to the low flow rate (less than $1 \mathrm{~L} / \mathrm{s}$ ) its contribution to the $\mathrm{Zn}$ load was limited. The main sources of contaminants were the mine-waste dumps on the river banks or widely dispersed along the stream as a consequence of erosional processes. Further contributions came from the inflow of water from abandoned mines or mineralized veins. The Rio Naracauli had neutral or slightly alkaline $\mathrm{pH}(7.6-8.4)$ and the chemical composition was $\mathrm{CaMg}-\mathrm{SO}_{4}$, whereas waters flowing from tailings had variable composition, mainly $\mathrm{Zn}-\mathrm{SO}_{4}$ (Medas et al., 2012; Podda et al., 2014). Of particular interest is the presence of Zn-rich phases: hydrozincite, a Zn hydroxycarbonate with the formula $\mathrm{Zn}_{5}\left(\mathrm{CO}_{3}\right)_{2}(\mathrm{OH})_{6}$, in the river section between 135 and $598 \mathrm{~m}$, and an amorphous Zn-silicate (which we refer to as "white mud") below the confluence of Rio Sa Roa. The precipitation of these phases is biologically mediated, hydrozincite by Scytonema sp. (Podda et al., 2000), and the white mud by Leptolyngbia frigida (Medas et al., 2014; Podda et al., 2014). In the upstream reach of Rio Naracauli, where the lowest Zn load was detected, hydrozincite formed white-yellowish incrustations on the riverbed. In this reach, there is a contribution of groundwater drainage from a mine- 

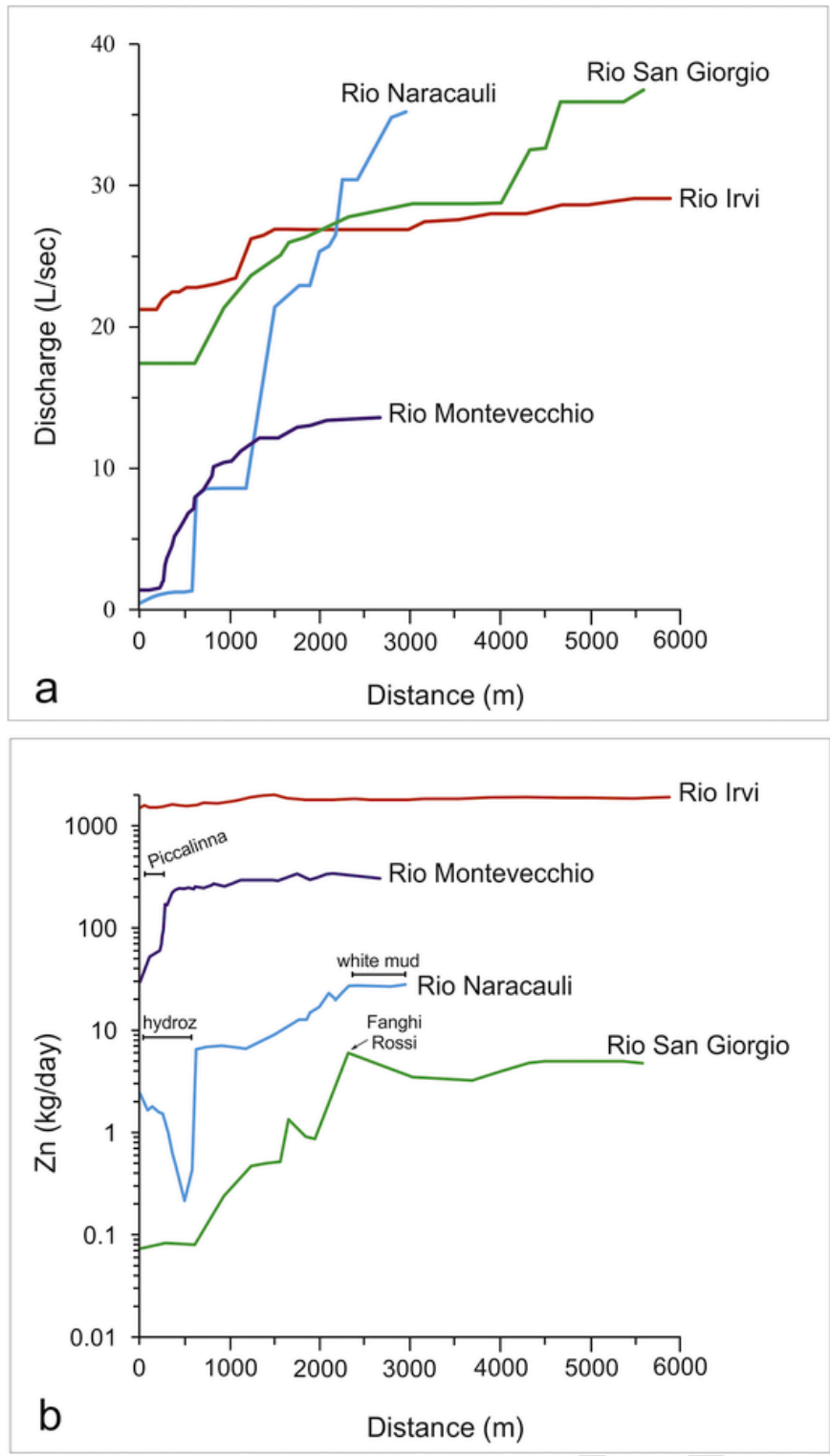

Fig. 3. a) Discharge and b) Zn loads (logarithmic scale) vs distance downstream of studied rivers. In the b) graph, the area of contribution of Piccalinna inflows on Rio Montevecchio; the areas of hydrozincite and white mud precipitation along the Rio Naracauli and the inflow of water from the Fanghi Rossi dump in the Rio San Giorgio are reported.

waste dump which added, other than $\mathrm{Zn}$, a considerable amount of $\mathrm{HCO}_{3}^{-}$, leading to particularly suitable conditions for hydrozincite precipitation (Figs. 2 and 3b; Wanty et al., 2013; De Giudici et al., 2014).

The Rio Irvi and Rio Montevecchio drain the mine area of Montevecchio, and are divided by the watershed into two catchments here referred to as Montevecchio West and Montevecchio East, respectively.

The Rio Montevecchio originates at the Montevecchio mine site, from the drainage gallery $n^{\circ} 173$ (Fig. 2) and flows for about $800 \mathrm{~m}$ near the Piccalinna impoundment, a waste dump mainly filled with flotation mud characterized by high levels of $\mathrm{Zn}(8.8 \mathrm{wt} \%)$ and $\mathrm{Pb}(1.1 \mathrm{wt} \%)$ (Buosi et al., 2001) and, to a lesser extent, by mine waste containing sulphide minerals. Rio Montevecchio receives contributions from mine adits and seepage at the bottom of Piccalinna and the main superficial inflows are waters from the Piccalinna gallery $n^{\circ} 172$ and Rio Struvoniga (Fig. 2). The discharge of Rio Montevecchio was about $1.4 \mathrm{~L} / \mathrm{s}$ along the first $150 \mathrm{~m}$ and, due to the contribution from Piccalinna impoundment, increased progressively up to $10.1 \mathrm{~L} / \mathrm{s}$ after the confluence of Rio Struvoniga $(819 \mathrm{~m})$, then continued to increase more slowly until the end of the study reach $(13.5 \mathrm{~L} / \mathrm{s}$ at $2661 \mathrm{~m}$; Fig. 3a). The composition of waters changed from $\mathrm{ZnCa}-\mathrm{SO}_{4}$ (upstream) to CaMg-SO ${ }_{4}$ (downstream) (De Giudici et al., 2019). The Rio Montevecchio reached $340 \mathrm{~kg} /$ day of $\mathrm{Zn}$ load. The major load of contaminants came from the Piccalinna impoundment, in fact, the increase of discharge within the first $800 \mathrm{~m}$ corresponded with a sharp increase of $\mathrm{Zn}$ load from $29.7 \mathrm{~kg} /$ day to $270 \mathrm{~kg} /$ day. Moreover, the decrease of $\mathrm{pH}$, from 5.9 to 4.0, could be attributable to the acid inflow of drainage galleries, spillages and tributaries derived from the Piccalinna impoundment. Downstream, the $\mathrm{pH}$ slightly increased ( $\mathrm{pH} 4.7-5)$, as a consequence of the buffering of tributary water interacting with carbonate minerals of Eocene limestone. In the first hundreds of meters the river received also the main loads of $\mathrm{SO}_{4}^{2-}$ and $\mathrm{Fe}$ (see Fig. 4 in De Giudici et al., 2019). The $\mathrm{SO}_{4}^{2-}$ ion increased constantly through the reach studied, whereas the Fe load decreased significantly because of the precipitation of Fe oxy/hydroxides. Zn showed low affinity for these Fe compounds, and was the least reactive among the contaminants determined in Rio Montevecchio (Frau et al., 2015; De Giudici et al., 2019).

The Rio Irvi receives the main contribution from the outflow of the Casargiu drainage gallery, flooded since 1997 due to the rebound of the water table following the mine closure (Frau et al., 2015). At the sampling time, the discharge from the gallery was $21.2 \mathrm{~L} / \mathrm{s}$ and increased up to $29.1 \mathrm{~L} / \mathrm{s}$ at the end of the study reach $(5872 \mathrm{~m})$. The most significant increment of discharge was observed within the first $1500 \mathrm{~m}$ downstream after the inflows of some tributaries; in this section the greatest observed value of about $2000 \mathrm{~kg} /$ day Zn load was reached. Further discharge came from dispersed groundwater in the final section of the study reach. The chemical composition of Rio Irvi was $\mathrm{ZnCaMg}-\mathrm{SO}_{4}$, with $\mathrm{pH}$ values ranging between 4.8 and 7.7 and tending to decrease downstream, except when receiving superficial inflow or groundwater (De Giudici et al., 2018). The Rio Irvi received the main load of contaminants from Casargiu outflow due to the intensive weathering of ore deposits, but a moderate increment was also produced by the superficial inflows. It is noteworthy that also considerable loads of $\mathrm{Fe}, \mathrm{SO}_{4}^{2-}$ and Mn were observed (see Fig. 6 in De Giudici et al., 2018). Interestingly, the Fe behaviour suggests the presence of biogeochemical processes which in turn influences the pattern of the other elements. Precipitation of Fe compounds, namely $\mathrm{Fe}(\mathrm{III})$ oxy/hydroxides and "green rust" (having a general formula $\mathrm{Fe}^{2+}{ }_{4} \mathrm{Fe}^{3+}{ }_{2}(\mathrm{OH})_{12}\left(\mathrm{SO}_{4}\right) \cdot 3 \mathrm{H}_{2} \mathrm{O}$; Frau et al., 2015), were visible as ochreous and green precipitates on the streambed. The formation of these minerals caused a decrease of water $\mathrm{pH}$ values toward slightly acid conditions. In this reach a small attenuation of $\mathrm{Zn}$ load was observed, probably due to the coprecipitation of $\mathrm{Zn}$ with colloidal $\mathrm{Fe}$. In the same reaches of stream, where the $\mathrm{Zn}$ load decreased, also $\mathrm{SO}_{4}^{2-}$ load losses were observed. The $\mathrm{SO}_{4}^{2-}$ decrease can be related in part with anion adsorption in the reach with low $\mathrm{pH}$, and in part with the precipitation in "green rust" (Cidu and Frau, 2009). On the other hand, $\mathrm{SO}_{4}^{2-}$ can be released into solution as the barely stable "green rust" ages to form the Fe(III) oxy/hydroxides (De Giudici et al., 2018).

\subsection{Microscopic processes along the streambeds}

Sediments in Rio San Giorgio and Rio Naracauli riverbed were visually recognizable; their thickness can attain $3 \mathrm{~m}$ and perhaps more. Sediments in Rio Montevecchio had a thickness varying from 0.3 to $1 \mathrm{~m}$ in the first $2 \mathrm{~km}$; while downstream the riverbed was covered by pebbles and reddish muds. Rio Irvi, on the contrary, is dominated by erosional processes; the riverbed is rocky with only local presence of fine-grained sediments. Core sediments were sampled in the Rio Montevecchio (core depth, $1 \mathrm{~m}$ ), Rio Naracauli (core depth, about $2 \mathrm{~m}$ ) and Rio San Giorgio (core depth, $3 \mathrm{~m}$ ) stream beds. In the last two riverbeds also samples of Phragmites australis were collected due 

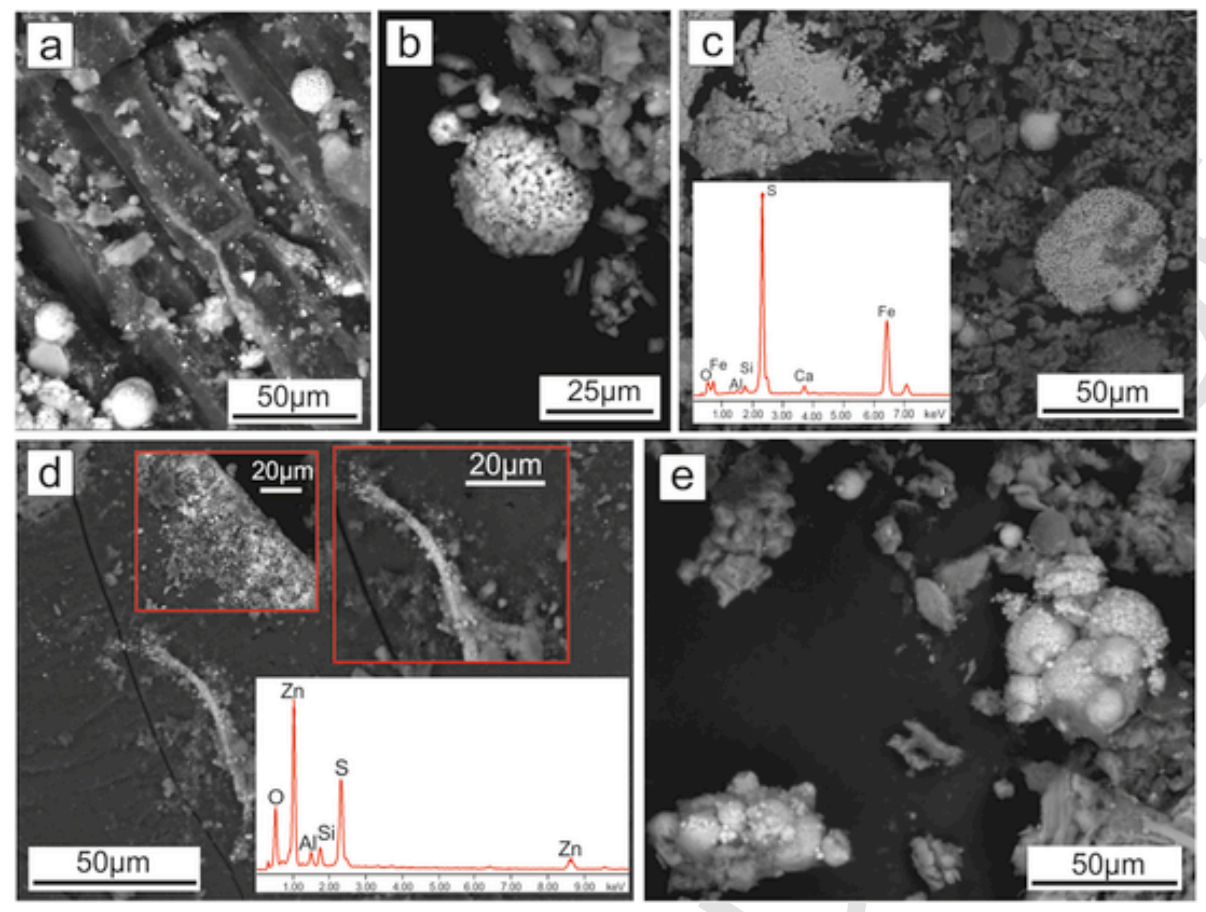

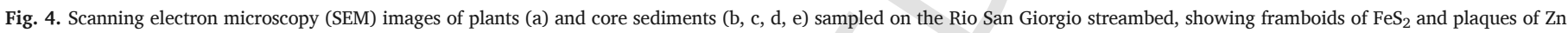
sulphides on the roots and in the rhizosphere of Phragmites australis.

to abundance of the plant and its significance in order to better understand the processes at the root-soil-water interface.

Core sediments sampled in the Rio San Giorgio riverbed consisted of unconsolidated sequences of reddish sand and grey silts and clays. XRD analyses indicated that the primary minerals consisted of sphalerite, galena, pyrite, goethite, hemimorphite and cerussite (De Giudici et al., 2017). SEM analyses of core sediments and plant tissues showed the presence of abundant framboidal pyrite in both sediments and root surfaces of Phragmites australis and Juncus acutus (Fig. 4). Element distribution and Zn speciation in Phragmites australis were investigated by LEXRF and XAS analysis, respectively (De Giudici et al., 2017). Results of LEXRF maps showed that $\mathrm{Fe}, \mathrm{Zn}, \mathrm{Si}$ and $\mathrm{Al}$ were mainly localized in the root epidermis. XAS analysis indicated that the $\mathrm{Zn}$ was present in the samples as both inorganic phases and organic compounds (hydrozincite, Zn-acetate-hydrate, smithsonite, and in cysteine and hydroxyapatite; De Giudici et al., 2017).

$\mathrm{Zn}$ load shows a peak at $2312 \mathrm{~m}$ from the injection point and a sharp decrease by around $3 \mathrm{~kg} /$ day at $3024 \mathrm{~m}$. Assuming this decrease per day to be roughly representative of the whole year allows us to estimate the total volume occupied by sphalerite or other zinc minerals per year. Considering the density of sphalerite or hydrozincite $\left(4.1\right.$ and $3.5 \mathrm{~g} / \mathrm{cm}^{3}$, respectively), we argued that the volume of $\mathrm{Zn}$ minerals formed in the reach $2312-3024 \mathrm{~m}$ averages 0.23 and $0.27 \mathrm{~m}^{3}$ /year. The whole volume of sediments in Rio San Giorgio averages $360,000 \mathrm{~m}^{3}$ (IGEA, 2011) while the volume of sediments of the reach $2312-3024 \mathrm{~m}$ has an area of $1500 \mathrm{~m}^{2}$ and, roughly, a volume of $1500 \mathrm{~m}^{3}$. A few core wells are available and indicate that the thickness can attain $3 \mathrm{~m}$, we assumed a reduced thickness of $1 \mathrm{~m}$ with reasonable underestimation. Thus, in the reach $2312-3024 \mathrm{~m}$, the ratio among volume of sediments and volume of secondary Zn minerals exceed 5000. This result indicates secondary minerals are very diluted in the sediments. Moreover, we argued that the biogeochemical barriers seem to have a potential activity of many hundreds of years, formally 5000 years. In the future, modelling can be implemented with more data on sedimentation rate and load measured under different hydrological regimes.
Core sediments of Rio Naracauli were sampled a few hundred meters downstream from the Brassey Mill tailing dump, in a highly vegetated area, where Phragmites australis and Juncus acutus were present (Fig. 2). Sediments consisted of unconsolidated sand and gravel layers alternating with consolidated clay layers, with sand lenses, characterized by the presence of abundant organic matter, especially roots. The main mineral phases, detected by XRD analyses, were quartz, feldspars, micas and clay minerals (muscovite, illite, kaolinite) in all levels, with subordinate minerals usually found in the ore deposits like carbonates (smithsonite, cerussite and siderite) and sulphides, and rarely jarosite. The SEM analyses of core sediments, in agreement with XRD analyses, showed a matrix of quartz, feldspars and phyllosilicates. At different depths of core sample, thin crusts or plaques of sulphides, especially of $\mathrm{Pb}$ and $\mathrm{Zn}$, commonly were observed in the rhizosphere and roots (Fig. 5). These incrustations were observed mainly in the deepest layers, but decreased closer to the surface. As observed for Rio San Giorgio, framboids of pyrite were detected. They consisted of sub-spheroidal micrometric clusters (10 - $20 \mu \mathrm{m}$ diameter) of octahedral crystals having maximum size up to $2 \mu \mathrm{m}$ (Fig. 6) and were mainly localized in the deeper layers (from 1.17 to about $2 \mathrm{~m}$ ). The STXM map of thin slices of Phragmites australis root collected in the Rio Naracauli riverbed is shown in Fig. 7. As observed in samples collected on the Rio San Giorgio riverbed, the LEXRF analysis showed that $\mathrm{Fe}, \mathrm{Zn}, \mathrm{Si}$ and $\mathrm{Al}$ are mainly localized in the root epidermis (Fig. 7c-f).

Sediments of Rio Montevecchio were characterized by yellow ochre-light brown sand layers with fine grey lenses and presence of clasts; moreover the presence of roots was detected in layers with fine sediments.

$\mathrm{XRD}$ analyses indicated the presence of quartz, muscovite and, in minor quantity, sulphides that were referred to as primary minerals (galena, sphalerite and pyrite), carbonates (ankerite and siderite) and sulphates (Atzori, 2013). Evidences of alteration of primary minerals were observed by SEM analyses (Fig. 8): for example, marks of acid-bacterial alteration, namely "etch pits" (Keller, 1982), were clearly recognizable on the surface of pyrite crystals (Fig. 8a-c). Also crystals of anglesite, precipitates of Fe oxy-hydroxides and altered galena were detected (Fig. 8d-f); moreover in the efflorescences sampled on 

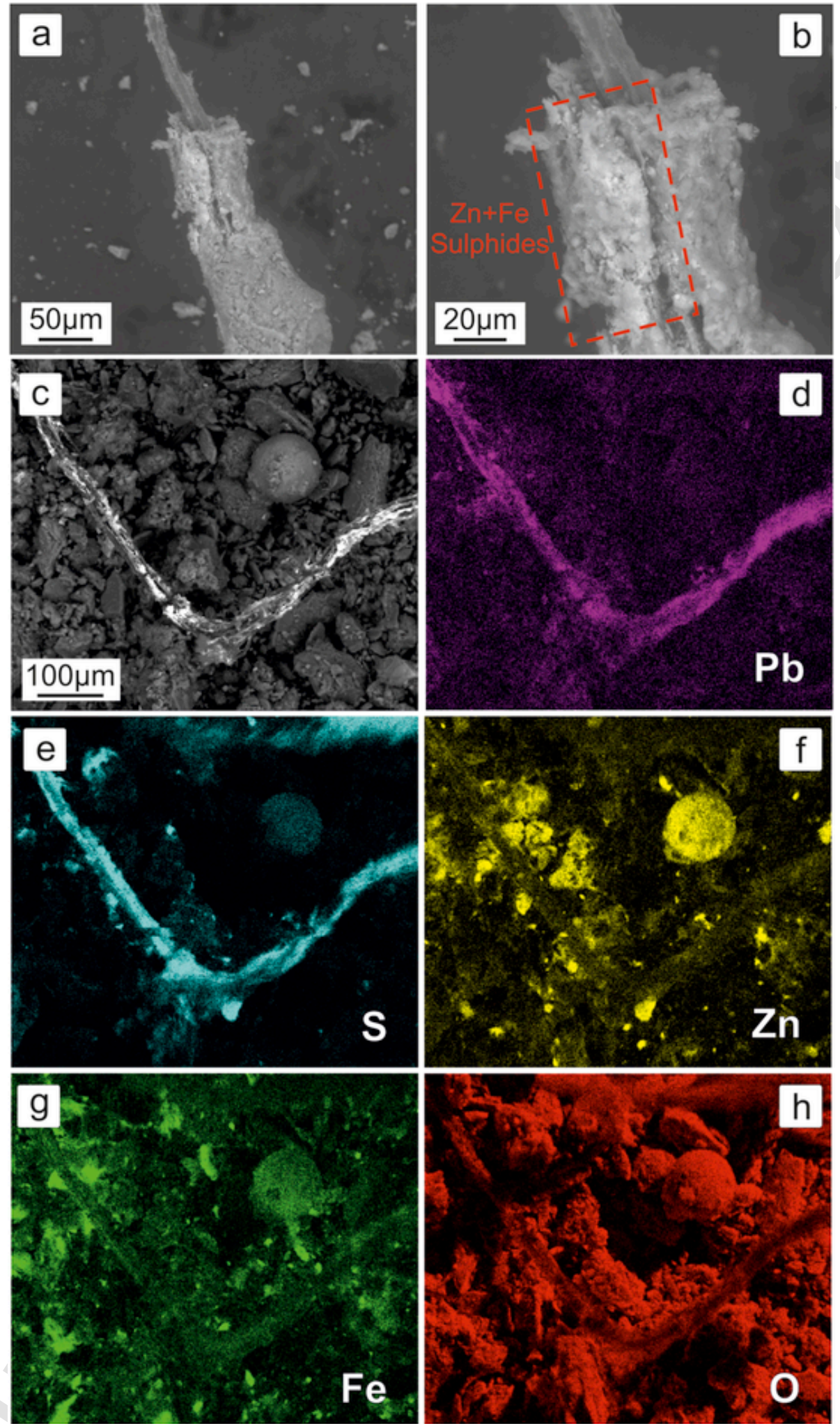

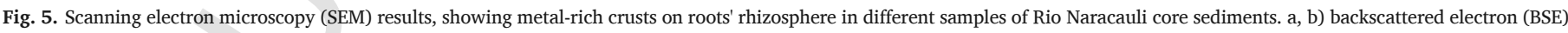

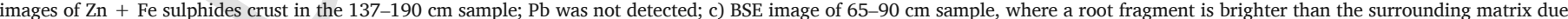

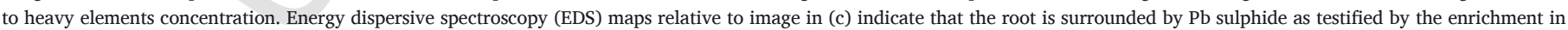

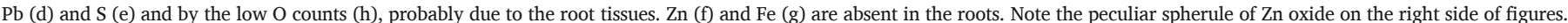



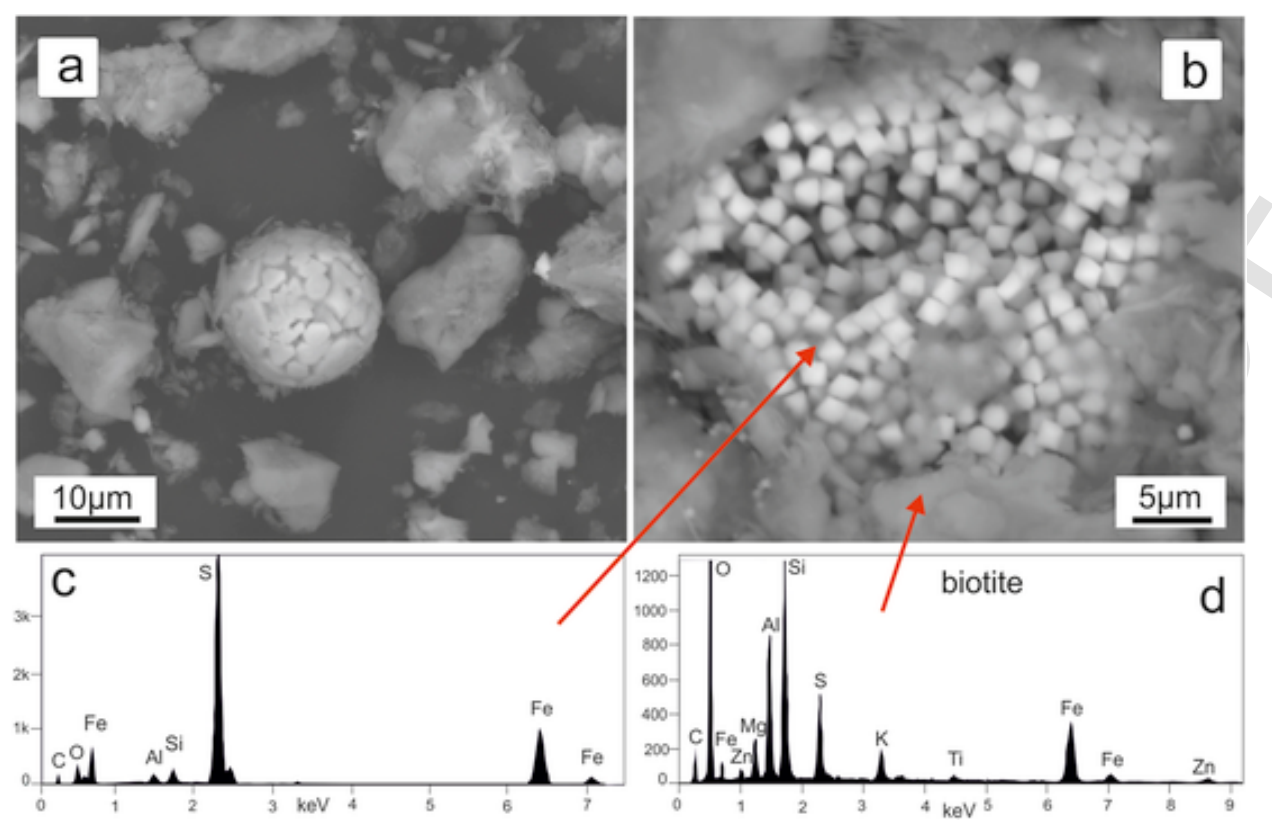

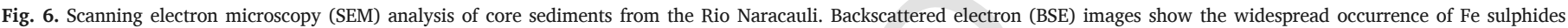

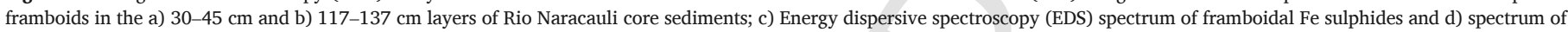
the surrounding mineral (biotite).

the Rio Montevecchio river bank, crystals of gypsum were observed (Fig. 8g).

\subsection{Secondary mineral formation can lead to environmental resilience}

The enhanced significance of environmental changes due to natural attenuation of dispersion processes in mining activities arose from an increased knowledge of the impacts that historical and active mining can have on the environment. Advances in the scientific understanding of the environmental impacts of past mining are crucial for new regulation meant to protect against these impacts. Moreover, knowledge of processes controlling natural attenuation is the basis for development of sustainable technologies. The impacts can be physical, chemical, and biological in nature, and their understanding requires a multidisciplinary array of expertise, including geologists, geochemists, hydrologists, microbiologists, and biologists. Processes that allow or prevent metal mobility at the microscale depend on the local physicochemical and biogeochemical conditions, which in turn depend on several factors like water discharge, soil porosity and permeability, density and type of vegetal coverage, and morphology of riverbed.

Riverbeds collect and drain the water that has interacted with rocks and minerals through the river catchment (Buxton et al., 1997; Kimball et al., 2002). For this reason, the knowledge of metal loads at different sections of a river is a unique tool to define the source of contaminants, the impact of geochemical and biogeochemical processes on mineral dissolution and precipitation, and to prioritize remediation action of the different mine-waste bodies in the catchment (Kimball et al., 2002).

Metal load values depend on processes controlling the interaction among different geological, industrial and ecological compartments. The most relevant factors are the presence and type of contamination source, the hydrological path, stability and reactivity of minerals, sedimentation or erosion regimes, geochemistry of rocks and waste, vegetation coverage, microbial composition and diversity, runoff, precipitation, sunlight irradiation and other weather conditions.

When the sedimentation regime dominates, sediments can accumulate along the riverbed allowing the growth of dense vegetal coverage with dense root systems, which in turn enhance the mechanical stability of the sediments (Ghestem et al., 2011). The macrophytes (e.g.
Phragmites australis, Juncus acutus, etc.) have a key role in the riverbed processes because they promote the sedimentation of suspended solids, limit erosive processes and provide organic matter that is a source of carbon for bacterial metabolism and sites for metal sorption (Marchand et al., 2010 and references therein). Plants and microorganisms can also favour the authigenic formation of secondary minerals in the hyporheic zone. Most macrophytes promote the formation of Fe-plaques (oxides, hydroxides and oxyhydroxides) by favouring oxidizing conditions at the roots. Metals may also be sequestered from solution and stored in vacuoles of root cells, or bioprecipitates under the root epidermis to limit their translocation (into shoots, stems and leaves) and thus the toxic effect (Shanker et al., 2005; Medas et al., 2019; Boi et al., 2020). Decomposition of organic matter and activity of sulphate-reducing bacteria lead to establishment of localized reducing conditions, where sulphate is reduced to dissolved sulphide and then precipitates as a metal-sulphide solid (Faulwetter et al., 2009). The rhizosphere is a preferred environment for many soil microorganisms, bacteria cover the root surface and often the mycelia of fungal mycorrhizae are symbiotic with roots of plants (Trapp and Karlson, 2001; Marchand et al., 2010). The presence of abundant root bodies covered by microbes may then facilitate the development of microbial biofilms within the soil. Density of vegetation and roots, as well as the thickness of sediments, are crucial factors for the biogeochemical activity of the hyporheic zone and, thus, for metal mobility across the whole riverbed system. For these reasons, the biogeochemical processes occurring at the hyporheic zone at the water-soil-plant interface can limit the metal mobility and then influence the water quality at the watershed scale (Runkel et al., 2003; Bencala, 2011; Byrne et al., 2014; De Giudici et al., 2017). In the Rio San Giorgio and Rio Naracauli the sedimentation regime dominated. On the contrary the erosion regime was dominant in Rio Montevecchio and Rio Irvi.

Microscopic observation of core samples and plant roots collected in Rio San Giorgio and Rio Naracauli showed the presence of abundant secondary minerals, probably promoted by both microorganism and plant activity. The observed metal sulphides $\left(\mathrm{FeS}_{\mathrm{x}}, \mathrm{PbS}, \mathrm{ZnS}\right.$ ) (Figs. 4, Figs. 5 and 6), in particular the presence of $\mathrm{FeS}_{2}$ framboids, suggest metal immobilization through the precipitation of metal-sulphides under reducing conditions mediated by sulphate-reducing microorganisms (Neumann et al., 2005; Gregory et al., 2014; Smieja-Król et 

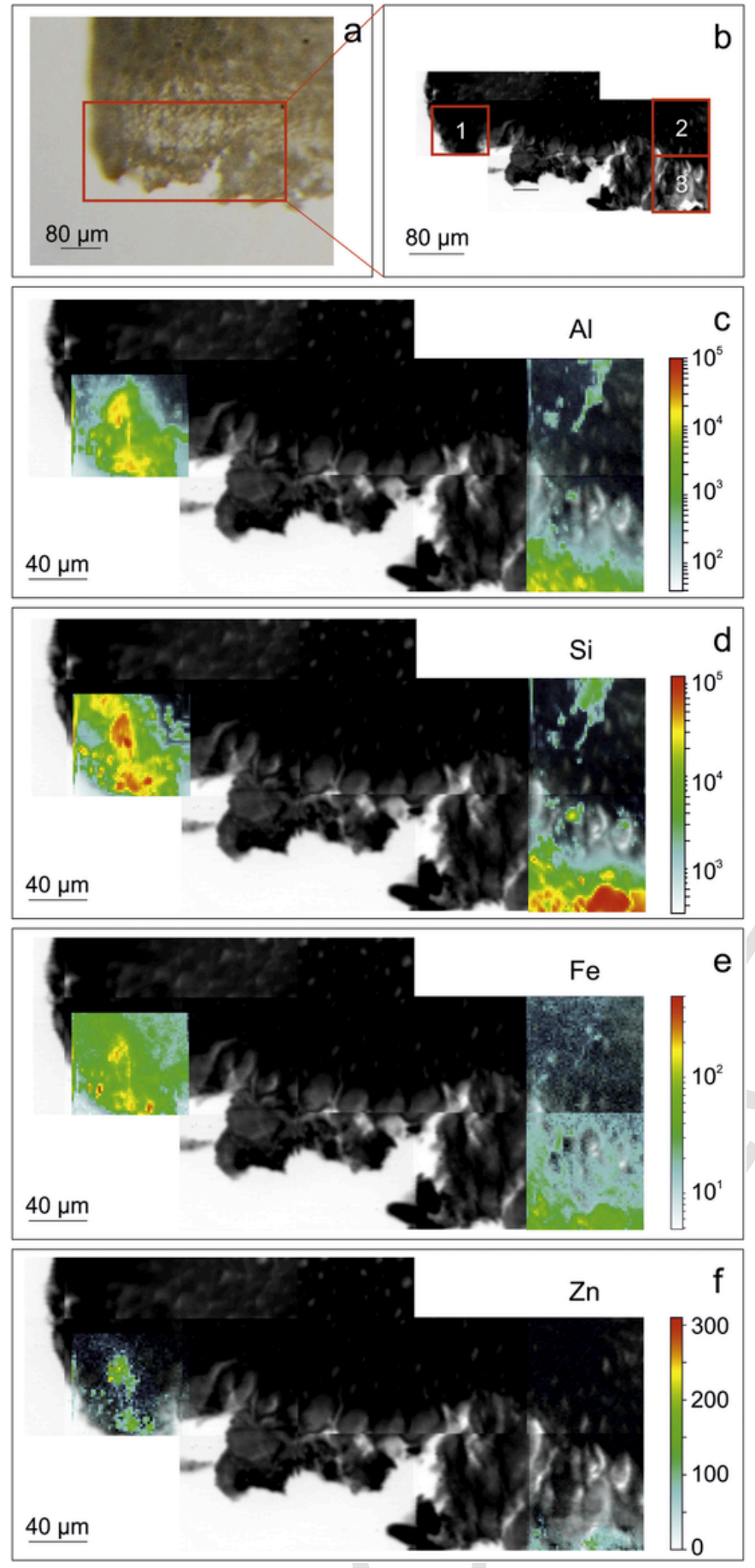

Fig. 7. Thin cross root section ( $14 \mu \mathrm{m})$ of Phragmites australis collected along the Rio Naracauli. a) Ordinary light stereo-microscope image with location of acquired maps, b) brightfield (absorption) images, and LEXRF maps of: c) Al, d) Si, e) Fe and f) Zn. Maps 1, size $80 \times 68 \mu \mathrm{m}^{2}$, scan $48 \times 42$ pixels, maps 2 and $3,80 \times 80 \mu \mathrm{m}^{2}$, scan $48 \times 48$ pixels.

al., 2015). The metal encrustations on the roots and rhizosphere may be an example of biomineralization triggered by plants to limit metal exposure by means of their precipitation.

In the natural systems investigated in this study, subjected to mining impacts with the consequent alteration of chemical and physical conditions, the above-mentioned processes can be interpreted as part of the adaptation of the environmental system to the perturbation, therefore as a part of the resilience of the system itself. At the same time, these processes lead to the formation of natural biogeochemical barriers.

For instance, the biomineralization observed in samples of Phragmites australis, being an adaptation strategy of $\mathrm{Zn}$ tolerant plants growing in polluted environments (Caldelas and Weiss, 2017), can be thought of as a resilience process that plays a significant role in the abatement of bioavailable metals, thus forming a biogeochemical barrier. Metal immobilization through bioprecipitation of metal sulphides, mediated by sulphate reducing bacteria, also can be a biogeochemical barrier. This mechanism, by limiting the metal loads, might help the development of vegetation that furnishes organic matter for microorganisms and helps to stabilize the sediments, improving the evolution of the area toward more stable conditions.

These processes have contributed to the progressive evolution/development of the hyporheic zone on the streambed of the Rio Naracauli in the last forty years. The aerial photos downstream from the Brassey tailing dump, from about 10 years after the mine closure (1968) to 2013 (Fig. 9), show an incipient low start of vegetal coverage followed by the progressive development, especially in the last ten years.

From 2007 up to now, through direct field monitoring, a progressive diffusion of Juncus acutus was observed, followed by the recent increasing presence of Phragmites australis. These field evidences, together with the development of vegetal coverage and the hyporheic zone, indicated that Juncus acutus is the pioneer $\mathrm{Zn}$ tolerant plant, and that the growth of Phragmites australis follows, as the system stabilizes. The presence of authigenic metal sulphide minerals indicates the attenuation of metal loads, however they could be a sink of pollutants in case of changes of redox conditions and subsequent sulphide oxidation (Smieja-Król et al., 2015; Noel et al., 2017). The persistence of favourable conditions ( $\mathrm{pH}, \mathrm{Eh}$, vegetal coverage, microbial activity, etc.) allows the efficiency of these biogeochemical barriers for a long time. Therefore, the dense vegetal coverage, the prevalence of Phragmites australis, and the consistent presence of metal sulphide, in particular Fe sulphides (framboids) suggest that Rio San Giorgio represents a more mature stage of natural environmental adaptation to mining impacts.

In sediment cores collected in Rio Montevecchio the presence of primary sulphides subjected to alteration and that of gypsum detected in the efflorescent salts, indicate the high reactivity of the system. The $\mathrm{Zn}$ load attenuation in both Rio Irvi and Rio Montevecchio is linked to adsorption/coprecipitation with Fe precipitates. In this case, the absence of authigenic metal sulphides suggests the absence or instability of the above mentioned resilient processes.

\section{Summary and conclusions}

Investigating the microscopic processes that control mineral dissolution and precipitation allows one to identify environmental processes, both positive and negative, leading to natural abatement or, rather, pollutant dispersion. These microscopic processes are the basis for increasing or decreasing metal loads in a river. When positive processes dominate, the load decreases or is limited; when negative processes dominate, the load increases and dispersion of pollutants may become a serious concern. In the investigated abandoned mining sites of Sardinia, the comparison among metal loads measured in the rivers shows that the impact of past mine activity varies over three orders of magnitude. A difference of such magnitude is not attributable to differences in river discharge, but to the kind of source and concurrent mineralogical and biogeochemical processes occurring in the hyporheic zone.

In Rio San Giorgio and Rio Naracauli, where the tracer analyses indicated the lowest metal loads, the microscopic investigation revealed that metal mobility was limited by the presence of biogeochemical barriers. Effective biogeochemical barriers consisted of sulphur reducing bacteria biofilms indicated by the presence of framboidal iron sulphides and $\mathrm{Zn}$ sulphides in sediment cores. These can be interpreted as ongoing authigenic formation of secondary phases that eventually form small authigenic ore deposits. In Rio Naracauli further biogeochemi- 

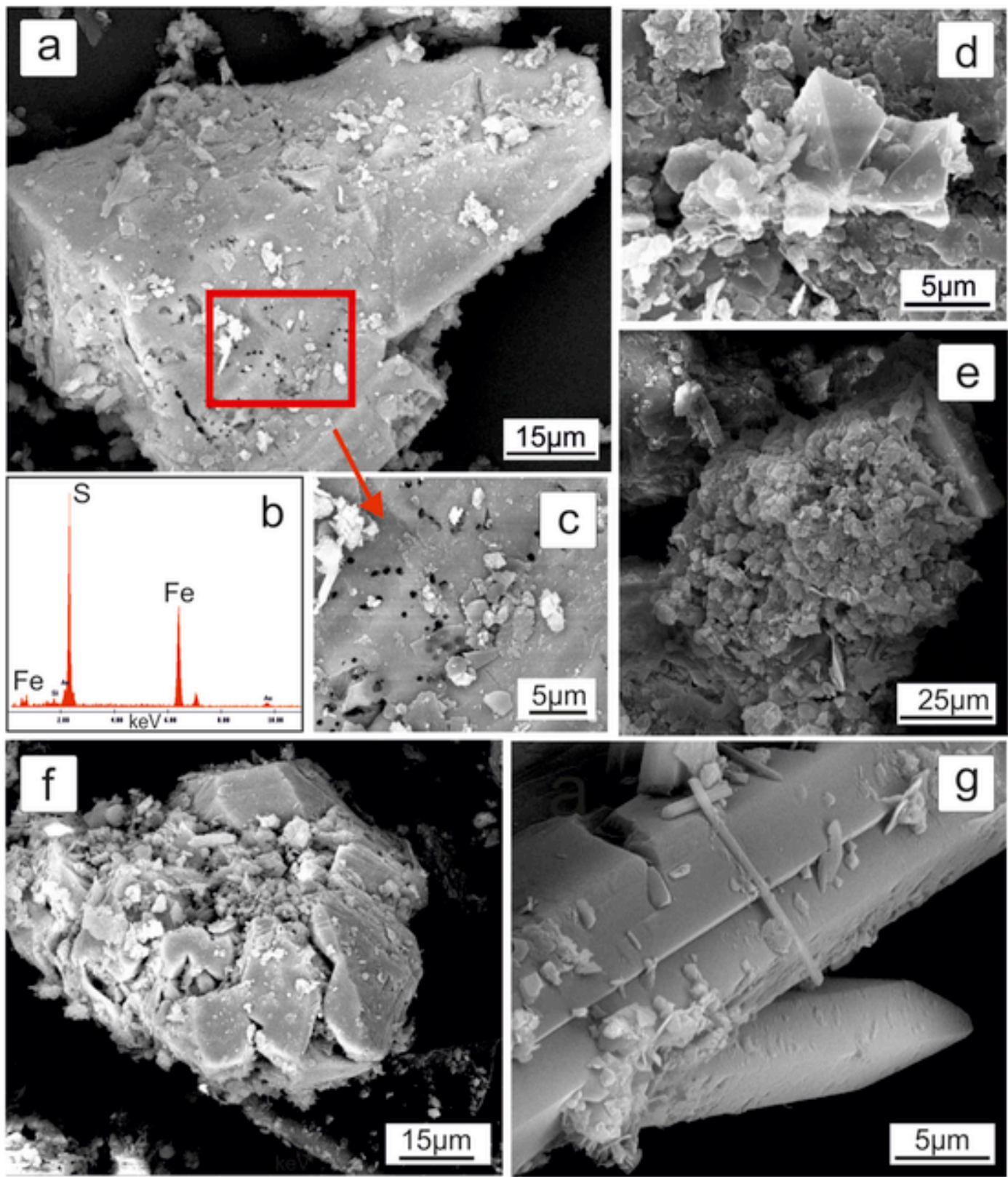

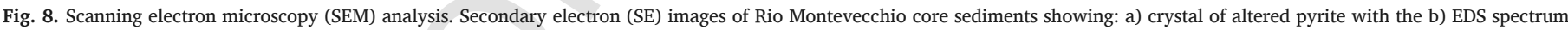

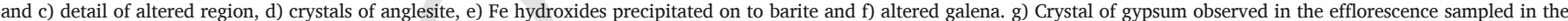
Montevecchio riverbank (Atzori, 2013, modified).

cal barriers are represented by seasonal cyanobacteria activity that controls the precipitation of $\mathrm{Zn}$ phases, especially hydrozincite. Other biogeochemical barriers were found in the rhizosphere around Phragmites australis and Juncus acutus, in their roots and stems where metals incorporation processes occur.

In conclusion, we argue that biogeochemical barriers can be an effective sink for metals in the catchment of the investigated historical mines. The formation of biominerals in the hyporheic zone can be seen as part of a resilient behaviour of the investigated system. For this reason, formation of secondary minerals and biogeochemical barriers must be assessed in the future to better define remediation actions and targets.

\section{Uncited References}

RAS, 2013; Stara et al., 1996.

\section{Declaration of competing interest}

The authors declare that they have no known competing financial interests or personal relationships that could have appeared to influence the work reported in this paper.

\section{Acknowledgments}

The authors acknowledge CESA (E58C16000080003) from RAS and RAS/FBS (F72F16003080002) grants, FP7 ERANETMED2 72094 SUPREME, the Grant of Excellence Departments, MIUR (ARTICOLO 1, COMMI 314-337 LEGGE 232/2016), and the CeSAR (Centro Servizi d'Ateneo per la Ricerca) of the University of Cagliari, Italy, for SEM analysis. This work has been supported by the POR FESR Sardegna 2014-2020 (project cluster Top-Down: TESTARE). The authors ac- 

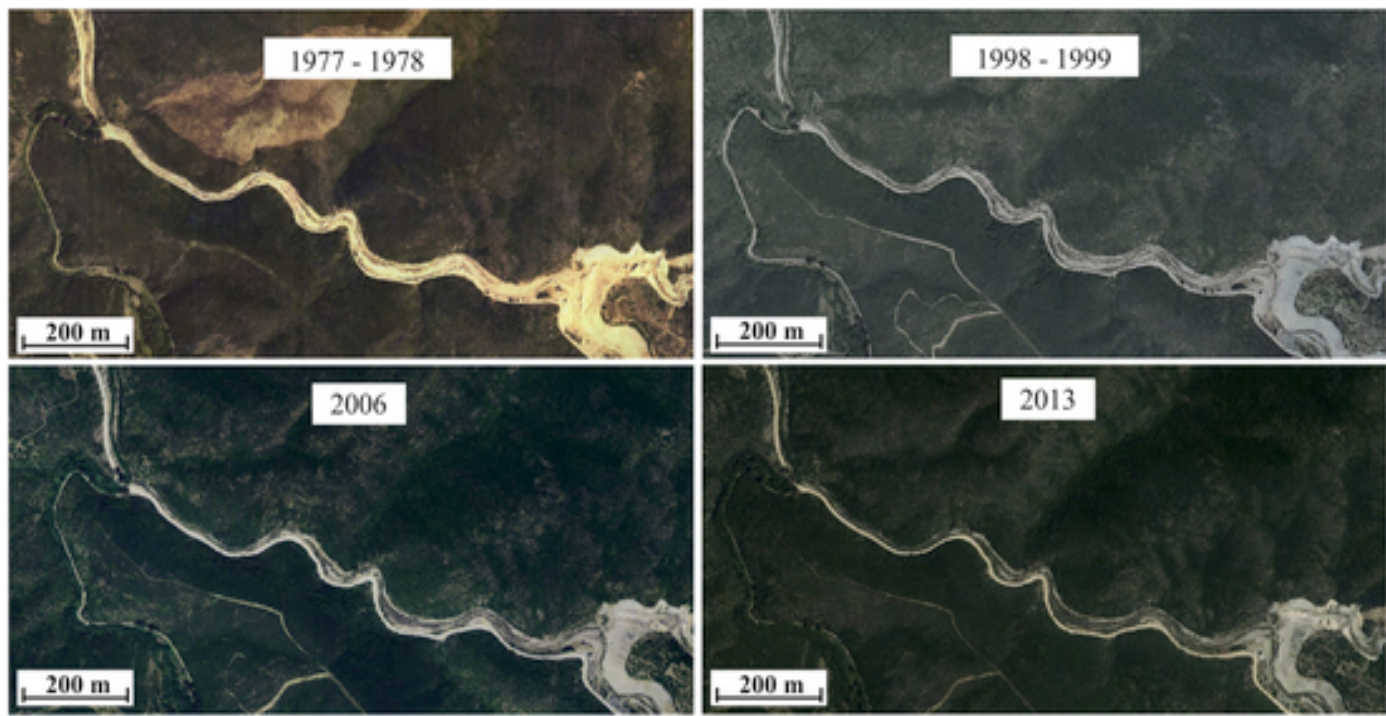

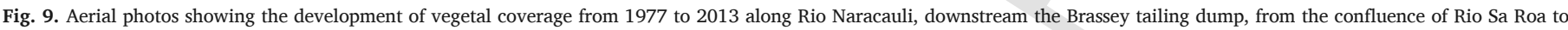
the end of the study reach (http://www.sardegnageoportale.it/webgis2/sardegnafotoaeree).

knowledge the CERIC-ERIC Consortium and the TwinMic beamline (grant number 20152020) for the access to experimental facilities and financial support. The Mineral Resources and the Toxic Substances Hydrology Programs of the US Geological Survey also supported this research.

Special thanks to Ilaria Frau and many students for their support in the tracer, and to Salvatore Vacca for his support during core sampling. Any use of trade, firm, or product names is for descriptive purposes only and does not imply endorsement by the U.S. Government. Editorial handling of Prof Pierpaolo Zuddas and suggestions of two anonymous reviewers are acknowledged.

\section{References}

An, J, Kim, J Y, Kim, K W, Park, J Y, Lee, J S, Jang, M, 2011. Natural attenuation of arsenic in the wetland system around abandoned mining area. Environ. Geochem. Health 33, 71-80.

Arbogast, B F, Knepper, D H, Langer, W H, 2000. The Human Factor in Mining Reclamation. U.S. Geol. Surv. Circular 119128.

Assorgia, A, Brotzu, P, Morbidelli, L, Nicoletti, M, Traversa, G, 1984. Successione e cronologia (K-Ar) degli eventi vulcanici del complesso calco-alcalino oligomiocenico dell'Arcuentu (Sardegna centro-occidentale). Period. Mineral. 53, 89-102.

Atzori, R, 2013. Studio mineralogico degli sterili nell'area vasta della miniera dismessa di Montevecchio Levante: processi mineralogici e dispersione dei metalli pesanti. Tesi di Laurea in Scienze e Tecnologie Geologiche 83 in Italian).

Batty, L C, Baker, A J M, Wheeler, B D, 2006. The effect of vegetation on porewater composition in a natural wetland receiving acid mine drainage. Wetlands $26,40-48$.

Bechstädt, Th, Boni, M (Eds.), 1994. Sedimentological, Stratigraphical and Ore Deposits Field Guide of the Autochthonous Cambro-Ordovician of Southwestern Sardinia: Servizio Geologico d'Italia Memorie Descritive Carta Geologica d'Italia. p. 434 XLVIII.

Bencala, K E, 2011. Stream-groundwater interactions. In: Wilderer, P (Ed.), Treatise on Water Science, Reference Module in Earth Systems and Environmental Sciences, 2. pp. 537-546.

Benfatto, M, Meneghini, C, 2014. A close look into the low energy region of the XAS spectra: the XANES region. In: Mobilio, S, Boscherini, F, Meneghini, C (Eds.), Synchrotron Radiation, Basic, Methods and Applications. Springer-Verlag, Berlin, pp. 213-240.

Boi, M E, Medas, D, Aquilanti, G, Bacchetta, G, Birarda, G, Cappai, G, Carlomagno, I, Casu, M A, Gianoncelli, A, Meneghini, C, Piredda, M, Podda, F, Porceddu, M, Rimondi, V, Vaccari, L, De Giudici, G, 2020. Mineralogy and Zn chemical speciation in a soil-plant system from a metal-extreme environment: a study on Helichrysum microphyllum subsp. tyrrhenicum (Campo Pisano mine, SW Sardinia, Italy). Minerals $10,259$.

Boni, M, 1994. Ores in southwestern Sardinia. Memorie Descrittive Carta Geologica d'Italia XLVIII, 155-184.

Boni, M, Gilg, H A, Aversa, G, Balassone, G, 2003. The "Calamine" of Southwetst Sardinia: geology, mineralogy, and stable isotope geochemistry of supergene $\mathrm{Zn}$ mineralization. Econ. Geol. 98, 731-748.

Buosi, M, Contini, E, Enne, R, Farci, A, Garbarino, C, Naitza, S, Tocco, S, 2001. Contributo alla conoscenza dei materiali delle discariche della miniera di
Monteponi: i 'Fanghi Rossi' dell'elettrolisi. Caratterizzazione fisico-geotecnica e chimico-mineralogica. Definizione del potenziale inquinante e proposte per possibili interventi. Atti Associazione Mineraria Sarda. Iglesias 99, 49-92 in Italian.

Buxton, H T, Nimick, D A, von Guerard, P, Church, S E, Frazier, A, Gray, J R, Lipin, B R, Marsh, S P, Woodward, D F, Kimball, B A, Finger, S E, Ischinger, L S, Fordham, J C, Power, M S, Bunck, C M, Jones, J W, 1997. A science-based, watershed strategy to support effective remediation of abandoned mine lands | USGS abandoned mine land initiative. In: ICARD Fourth International Conference on Acid Rock Drainage (Vancouver)

Byrne, P, Binley, A, Heathwaite, A L, Ullah, S, Heppell, C M, Lansdown, K, Zhang, H, Trimmer, M, Keenan, P, 2014. Control of river stage on the reactive chemistry of the hyporheic zone. Hydrol. Process. 28, 4766-4779. doi:10.1002/hyp.998.

Caldelas, C, Weiss, D J, 2017. Zinc Homeostasis and isotopic fractionation in plants: a review. Plant Soil 411, 17-46.

Carmignani, L, Barca, S, Oggiano, G, Pertusati, I, Conti, P, Eltrudis, A, Funedda, A, Pasci, S, 1996. Carta Geologica Della Sardegna 1:200.000. Serv Geol d'Italia.

Cecchi, G, Marescotti, P, Di Piazza, S, Zappatore, S, Zotti, M, 2019. Fungal richness in the extreme environments of the Libiola mine (eastern Liguria, Italy): correlation among microfungi, lithology, mineralogy, and contaminants. Environ. Earth Sci. 78, 541. doi:10.1007/s12665-019-8553-0.

Cecchi, G, Ceci, A, Marescotti, P, Persiani, A M, Di Piazza, S, Zotti, M, 2019. Interactions among microfungi and pyrite-calcopyrite mineralizations: tolerance, mineral biolaching, and metal bioaccumulation. Mycol. Prog. 18, 415-423. doi:10.1007/ s11557-018-01466-y.

Cecchi, G, Di Piazz, S, Marescotti, P, Zotti, M, 2019. Evidence of pyrite dissolution by telephora terrestris ehrh in the libiola mine (sestri levante, liguria, Italy). Heliyon 5 , e02210. doi:10.1016/j.heliyon.2019.e02210.

Cidu, R, Fanfani, L, 2002. Overview of the environmental geochemistry of mining districts in southwestern Sardinia, Italy. Geochemistry Explor. Environ. Anal. 2, 243-251.

Cidu, R, Frau, F, 2009. Impact of the Casargiu mine drainage (sw Sardinia, Italy) on the Mediterranean Sea. In: International Mine Water Conference 19th - 23rd October 2009 Proceedings. pp. 926-931.

Cuccuru, S, Naitza, S, Secchi, F, Puccini, A, Casini, L, Pavanetto, P, Linnemann, U, Hofmann, M, Oggiano, G, 2016. Structural and metallogenic map of late variscan arbus pluton (SW Sardinia, Italy). J. Maps 12 (5), 860-865.

De Giudici, G, Wanty, R B, Podda, F, Kimball, B A, Verplanck, P L, Lattanzi, P, Cidu, R, Medas, D, 2014. Quantifying biomineralization of zinc in the Rio Naracauli (Sardinia, Italy), using a tracer injection and synoptic sampling. Chem. Geol. 384, 110-119.

De Giudici, G, Medas, D, Meneghini, C, Casu, M A, Gianoncelli, A, Iadecola, A, Podda, S, Lattanzi, P, 2015. Microscopic biomineralization processes and Zn bioavailability: synchrotron-based investigation of Pistacia lentiscus L. roots. Environ. Sci. Pollut. Res. 22-24, 19352-19361.

De Giudici, G, Pusceddu, C, Medas, D, Meneghini, C, Gianoncelli, A, Rimondi, V, Podda, F, Cidu, R, Lattanzi, P, Wanty, R B, Kimball, B, 2017. The role of natural biogeochemical barriers in limiting metal loading to a stream affected by mine drainage. Appl. Geochem. 76, 124-135.

De Giudici, G, Medas, D, Cidu, R, Lattanzi, P, Podda, F, Frau, F, Rigonat, N, Pusceddu, C, Da Pelo, S, Onnis, P, Marras, P A, Wanty, R B, Kimball, B, 2018. Application of hydrologic-tracer techniques to the Casargiu Adit and Rio Irvi (SW-Sardinia, Italy): using enhanced natural attenuation to reduce extreme metal loads. Appl. Geochem. 96, 42-54.

De Giudici, G, Medas, D, Cidu, R, Lattanzi, P, Rigonat, N, Frau, I, Podda, F, Marras, P A Dore, E, Frau, F, Rimondi, V, Runkel, R L, Wanty, R B, Kimball, B, 2019. Assessmen of origin and fate of contaminants along mining-affected Rio Montevecchio 
(SW Sardinia, Italy): a hydrologic-tracer and environmental mineralogy study. Appl. Geochem. 109, 104420.

Di Cicco, A, Aquilanti, G, Minicucci, M, Principi, E, Novello, N, Cognigni, A, Olivi, L, 2009. Novel XAFS capabilities at ELETTRA synchrotron light source. J. Phys. Conf. Ser. 190, 12043. doi:10.1088/1742-8306596/190/1/012043.

Eurostat Land cover statisticsData from July 2017http://ec.europa.eu/eurostat/ statisticsexplained/index.php/Land cover_stati-stics2012

Faulwetter, J L, Gagnon, V, Sundberg, C, Chazarenc, F, Burr, M D, Brisson, J, Camper, A $\mathrm{K}$, Stein, O, 2009. Microbial processes influencing performance of treatment wetlands: a review. Ecol. Eng. 35, 987-1004.

Frau, F, Medas, D, Da Pelo, S, Wanty, R B, Cidu, R, 2015. Environmental effects on the aquatic system and metal discharge to the mediterranean sea from a near-neutral zinc-ferrous sulfate mine drainage. Water Air Soil Pollut. 226. doi:10.1007/ s11270-015-2339-0.

Ghestem, M, Sidle, R C, Stokes, A, 2011. The influence of plant root systems of subsurface flow: implications for slope stability. Bioscience 61 (11), 869-879.

Gianoncelli, A, Morrison, G R, Kaulich, B, Bacescu, D, Kovac, J, 2006. A fast readout CCD camera system for scanning X-ray microscopy. Appl. Phys. Lett. 89, 251117-251119.

Gianoncelli, A, Kaulich, B, Alberti, R, Klatka, T, Longoni, A, de Marco, A, Marcello, A, Kiskinova, M, 2009. Simultaneous soft X-ray transmission and emission microscopy. Nucl. Instrum. Methods 608, 195-198.

Gianoncelli, A, Kourousias, G, Stolfa, A, Kaulich, B, 2013. Recent developments at the TwinMic beamline at ELETTRA: an 8 SDD detector setup for low energy Xray. J. Phys. Conf. Ser. 425, 182001.

Gianoncelli, A, Kourousias, G, Altissimo, M, Bedolla, D, Merolle, L, Stolfa, A, Shin, H, 2016. Combining multiple imaging techniques at the TwinMic X-ray microscopy beamline. AIP Conference Proceedings 1764-Y, 030002.

Gianoncelli, A, Kourousias, G, Merolle, L, Altissimo, M, Bianco, A, 2016. Current status of the TwinMic beamline at Elettra: a soft X-ray transmission and emission microscopy stat. J. Synchrotron Radiat. 23, 1526-1537.

Gollner, S, Kaiser, S, Menzel, L, et al., 2017. Resilience of benthic deep-sea fauna to mining activities. Mar. Environ. Res. 129, 76-101.

Gregory, D, Meffre, S, Large, R, 2014. Comparison of metal enrichment in pyrite framboids from a metal-enriched and metal-poor Estuary. Am. Mineral. 99, 633-644.

Holling, C S, 1973. Resilience and stability of ecological systems. Annu. Rev. Ecol. Systemat. 4, 1-23.

Igea, 2011. Progetto per il risanamento ambientale del Rio San Giorgio, Valle di Iglesias e ed il sistema marino costiero di Fontanamare.

Igiri, B E, Okoduwa, S I R, Idoko, G O, Akabuogu, E P, Adeyi, A O, Ejiogu, I K, 2018. Toxicity and bioremediation of heavy metals contaminated ecosystem from Tannery Wastewater: a Review. J. Toxicol. 2568038.

Kaulich, B, Bacescu, D, Susini, J, David, C, Di Fabrizio, E, Morrison, G R, Charalambous, P, Thieme, J, Wilhein, T, Kovac, J, Cocco, D, Salome, M, Dhez, O, Weitkamp, T, Cabrini, S, Cojoc, D, Gianoncelli, A, Vogt, U, Podnar, M, Zangrando, M, Zacchigna, M, Kiskinova, M, 2006. Proc. 8th Int. Conf. X-ray Microscopy IPAP Conf. Series 7, 22.

Keller, L, 1982. Acid-bacterial and ferric sulphate leaching of pyrite single crystals. Biotechnol. Bioeng. XXIV, 83-96.

Kimball, B A, Runkel, R L, Walton-Day, K, Bencala, K E, 2002. Assessment of metal loads in watershed affected by acid mine drainage by using tracer injection and synoptic sampling: cement Creek, Colorado, USA. Appl. Geochem. 17, 1183-1207.

Lin, G C S, Ho, S P S, 2003. China's land resources and land-use change: insights from the 1996 land survey. Land Use Pol. 20, 87-107. doi:10.1016/S0264-8377(03)00007-3.

Marchand, L, Mench, M, Jacob, D L, Otte, M L, 2010. Metal and metalloid removal in constructed wetlands, with emphasis on the importance of plants and standardized measurements: a review. Environ. Pollut. 158, 3447-3461.

Medas, D, Cidu, R, Lattanzi, P, Podda, F, Wanty, R B, De Giudici, G, 2012. Hydrozincite seasonal precipitation at (Naracauli Sardinia - Italy): hydrochemical factors and morphological features of the biomineralization process. Appl. Geochem. 27, 1814-1820.

Medas, D, Lattanzi, P, Podda, F, Meneghini, C, Trapananti, A, Sprocati, A, Casu, M A, Musu, E, De Giudici, G, 2014. The amorphous Zn biomineralization at Naracauli stream, Sardinia: electron microscopy and X-ray absorption spectroscopy. Environ. Sci. Pollut. Res. 21, 6775-6782.

Medas, D, De Giudici, G, Casu, M A, Musu, E, Gianoncelli, A, Iadecola, A, Meneghini, C, Tamburini, E, Sprocati, A R, Turnau, K, Lattanzi, P, 2015. Microscopic processes ruling the bioavailability of Zn to roots of Euphorbia pithyusa L. Pioneer plant. Environ. Sci. Technol. 49, 1400-1408.

Medas, D, De Giudici, G, Pusceddu, C, Casu, M A, Birarda, G, Vaccari, L, Gianoncelli, A, Meneghini, C, 2019. Impact of Zn excess on biomineralization processes in Juncus acutus grown in mine polluted sites. J. Hazard Mater. 370, 98-107.

Meneghini, C, Bardelli, F, Mobilio, S, 2012. ESTRA-FitEXA: a software package for EXAFS data analysis. Nucl. Instrum. Methods B 285, 153-157.

Moroni, M, Naitza, S, Ruggieri, G, Aquino, A, Costagliola, P, De Giudici, G, Caruso, S, Ferrari, E, Fiorentini, M L, Lattanzi, P, 2019. The Pb-Zn-Ag vein system at Montevecchio-Ingurtosu, southwestern Sardinia, Italy: a summary of previous knowledge and new mineralogical, fluid inclusion, and isotopic data. Ore Geol. Rev. 115, 103194.

Morrison, G R, Gianoncelli, A, Kaulich, B, Bacescu, D, Kovac, J, 2006. A fast read-out CCD system for configurated-detector imaging in STXM. Conf. Proc. Ser. IPAP 7, 277-379.

Neumann, T, Rausch, N, Leipe, T, Dellwig, O, Berner, Z, Böttcher, M E, 2005. Intense pyrite formation under low-sulfate conditions in the Achterwasser lagoon, SW Baltic Sea. Geochem. Cosmochim. Acta 69, 14 3619-3630. doi:10.1016/j.gca.2005.02.034.

Noel, V, Juillot, F, Morin, G, Marchand, C, Ona-Nguema, G, Viollier, E, Prévot, F, Dublet, G, Maillot, F, Delbes, L, Marakovic, G, Bargar, J R, Brown, G E, Jr., 2017. Oxidation of Ni- rich mangrove sediments after isolation from the sea (Dumbea Bay, New Caledonia): Fe and Ni behaviour and environmental implications. ACS Earth Space Chem 1, 455-464. doi:10.1021/acsearthspacechem.7b00005.

Pillola, G L, Leone, F, Loi, A, 1998. The cambrian and early ordovician of SW Sardinia. Giorn. Geol. 60 (3), 25-38 Special lssue ECOS V/1-Sardinia Guide-book.

Podda, F, Zuddas, P, Minacci, A, Pepi, M, Baldi, F, 2000. Heavy metal coprecipitation with hydrozincite $\left[\mathrm{Zn}_{5}\left(\mathrm{CO}_{3}\right)_{2}(\mathrm{OH})_{6}\right]$ from mine waters caused by photosynthetic microorganisms. Appl. Environ. Microbiol. 66, 5092-5098.

Podda, F, Medas, D, De Giudici, G, Ryszka, P, Wolowski, K, Turnau, K, 2014. Zn biomineralization processes and microbial biofilm in a metal-rich stream (Naracauli, Sardinia). Environ. Sci. Pollut. Res. 21, 6793-6808.

RAS http://www.regione.sardegna.it $/ \mathrm{j} / \mathrm{v} / 25 ? \mathrm{~s}=131338 \& \mathrm{v}=2 \& \mathrm{c}=5650 \& \mathrm{t}=1$

R.A.S, 1998. Nuovo studio dell'idrologia superficiale della Sardegna. Regione Autonoma della Sardegna, Cagliari, Ente Autonomo del Flumendosa (Scientific Responsible: C. Cao Pinna). Cagliari (in Italian).

No Title [WWW Document]RAS Ser. Stor. delle altezze di precipitazione giornaliera dal 1922 al 2010http://www.regione.sardegna.it $/ \mathrm{j} / \mathrm{v} / 25 ? \mathrm{~s}=131338 \& \mathrm{v}=2 \& \mathrm{c}=5650 \&$ $\mathrm{t}=12013$

Rice, K C, Herman, J S, 2012. Acidification of hearth: an assessment across mechanisms and scales. Appl. Geochem. 27, 1-14.

Runkel, R L, McKnight, D M, Rajaram, H, 2003. Modeling hyporheic zone processes. Adv. Water Resour. 26-9, 901-905.

Shanker, A K, Cervantes, C, Loza-Tavera, H, Avudainayagam, S, 2005. Chromium toxicity in plants. Environ. Int. 31, 739-753.

Sheoran, A S, Sheoran, V, 2006. Heavy metal removal mechanism of acid mine drainage in wetlands: a critical review. Miner. Eng. 19, 105-116.

Smieja-Król, B, Janeczek, J, Bauerek, A, Thorseth, I H, 2015. The role of authigenic sulphides in immobilization of potentially toxic metals in the Bagno Bory wetland, southern Poland. Environ. Sci. Pollut. Res. 22, 15495-15505.

Sole, A, Papillon, E, Cotte, M, Walter, P, Susini, J, 2007. A multiplatform code for the analysis of energy-dispersive X-ray fluorescence spectra. Spectrochim. Acta B 62-1, 63-68.

Stara, P, Rizzo, R, Tanca, G A, 1996. Iglesiente e Arburese. Miniere e Minerali. EMSA, Cagliari.

Trapp, S, Karlson, U, 2001. Aspects of phytoremediation of organic pollutants. J. Soils Sediments 1, 37-43.

Walaszek, M, Del Nero, M, Bois, P, Ribstein, L, Courson, O, Wanko, A, Laurent, J, 2018. Sorption behaviour of copper, lead and zinc by a constructed wetland treating stormwater. Appl. Geochem. 97, 167-180.

Wanty, R B, Podda, F, De Giudici, G, Cidu, R, Lattanzi, P, 2013. Zinc isotope and transition-element dynamics accompanying hydrozincite biomineralization in the Rio Naracauli, Sardinia, Italy. Chem. Geol. 337, 1-10.

Yang, Y, Erskine, P D, Zhang, S, Wang, Y, Bian, Z, Lei, S, 2018. Effects of underground mining on vegetation and environmental patterns in a semi-arid watershed with implications for resilience management. Environ. Earth Sci. 77, 605. doi:10.1007/ s12665-018-7796-5. 